
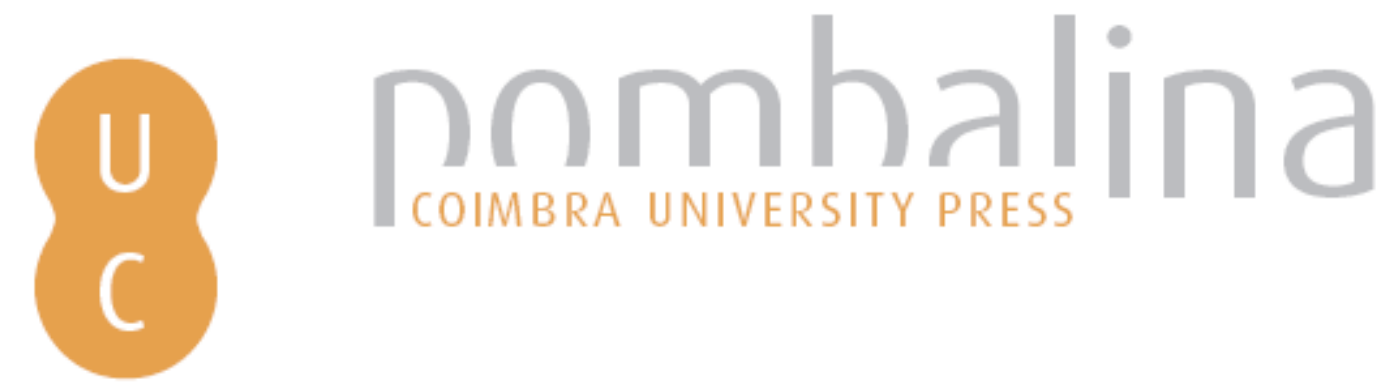

\title{
Contornos da nação em cinejornais democráticos e antidemocráticos
}

\author{
Autor(es): $\quad$ Archangelo, Rodrigo \\ Publicado por: Imprensa da Universidade de Coimbra \\ URL \\ persistente: URI:http://hdl.handle.net/10316.2/39002 \\ DOI: $\quad$ DOI:http://dx.doi.org/10.14195/978-989-26-1064-1_8
}

Accessed : $\quad$ 26-Apr-2023 00:38:19

A navegação consulta e descarregamento dos títulos inseridos nas Bibliotecas Digitais UC Digitalis, UC Pombalina e UC Impactum, pressupõem a aceitação plena e sem reservas dos Termos e Condições de Uso destas Bibliotecas Digitais, disponíveis em https://digitalis.uc.pt/pt-pt/termos.

Conforme exposto nos referidos Termos e Condições de Uso, o descarregamento de títulos de acesso restrito requer uma licença válida de autorização devendo o utilizador aceder ao(s) documento(s) a partir de um endereço de IP da instituição detentora da supramencionada licença.

Ao utilizador é apenas permitido o descarregamento para uso pessoal, pelo que o emprego do(s) título(s) descarregado(s) para outro fim, designadamente comercial, carece de autorização do respetivo autor ou editor da obra.

Na medida em que todas as obras da UC Digitalis se encontram protegidas pelo Código do Direito de Autor e Direitos Conexos e demais legislação aplicável, toda a cópia, parcial ou total, deste documento, nos casos em que é legalmente admitida, deverá conter ou fazer-se acompanhar por este aviso.

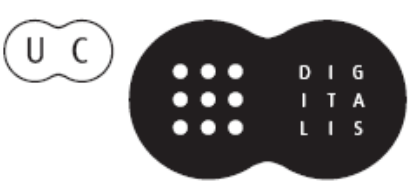


A L B ERTO PENA-RODR ÍGUEZ HELOISA PAULO

COOR D.

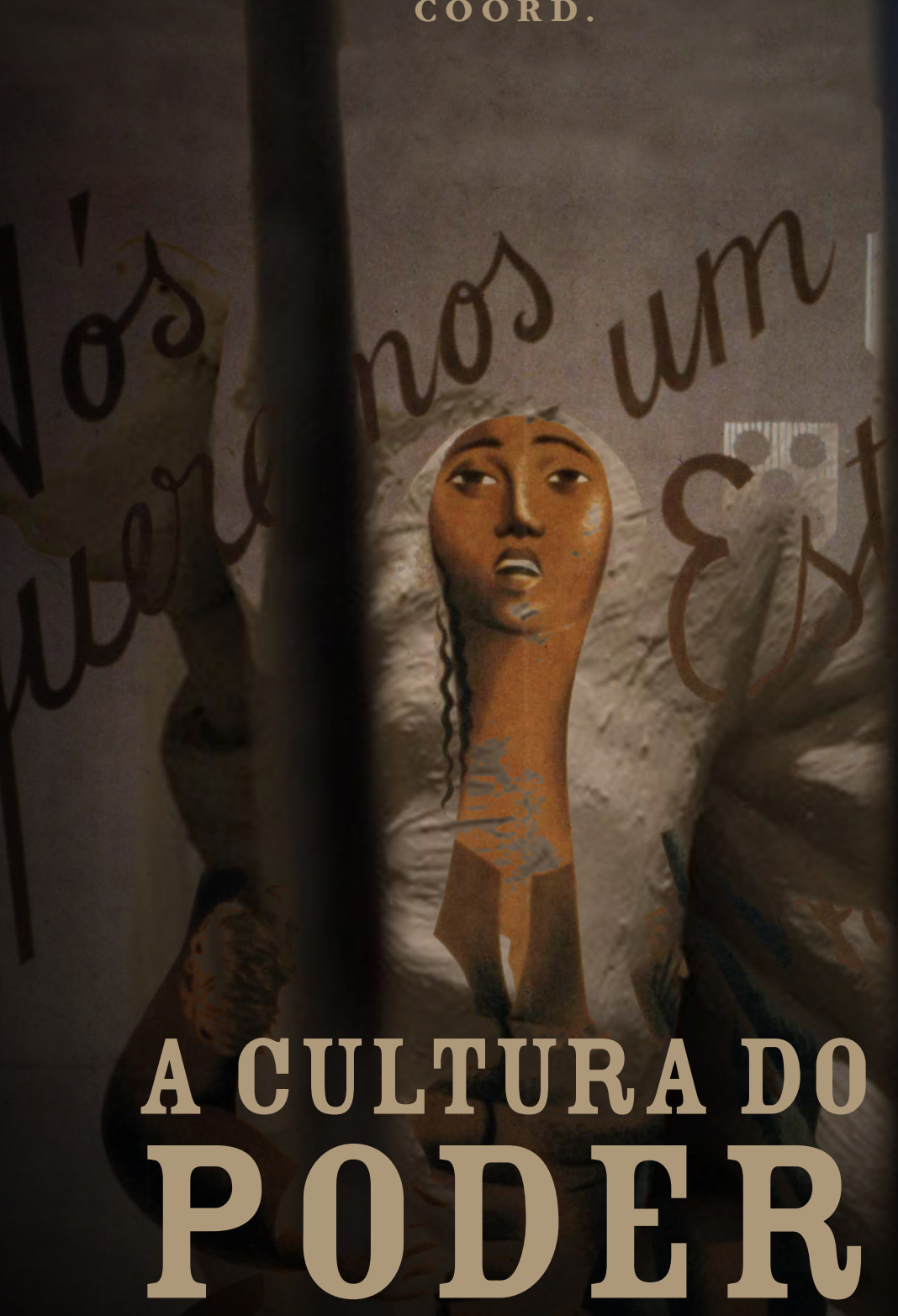

A PROPAGANDA INOS ESTADOS AUTORITÁRIOS 


\section{CONTORNOS DA NAÇÃO EM CINEJORNAIS DEMOCRÁTICOS E ANTIDEMOCRÁTICOS}

Rodrigo Archangelo

Constituídos por imagens e sons que propagandearam os "donos" do poder político e econômico durante o século $\mathrm{XX}$, muitos cinejornais ultrapassam este propósito quando submetidos ao olhar histórico. A variedade e a circularidade de temas semanalmente noticiados, somados aos aspectos formais de inúmeros títulos que compõem uma tradição de jornais cinematográficos no Brasil, são dados significativos à compreensão das transformações políticas, econômicas e socioculturais da sociedade brasileira. A partir da análise de três cinejornais produzidos em diferentes momentos, levantaremos alguns contornos do que foi transmitido por eles como ideal de nação num curto espaço de 32 anos na história do Brasil, situados entre 1938 e 1970. Com as séries Cine Jornal Brasileiro, entre 1938 e 1945; Notícias da Semana e Atualidades Atlântida, entre os anos 1956 e 1960; e Canal 100 Jornal em 1970, observaremos os rituais ${ }^{1}$ numa cultura do poder que embasou o discurso

${ }^{1} \mathrm{Na}$ literatura sobre o cinema brasileiro, o termo "ritual do poder" significa, resumidamente, o autoelogio das elites políticas e econômicas em seus atos públicos e privados. Trata-se de um conceito já estabelecido nas discussões sobre o cinema no Brasil, e que foi proposto pelo crítico e professor de cinema Paulo Emílio Salles Gomes - juntamente com a contrapartida "berço esplêndido", a exaltação das belezas naturais e culturais do Brasil. $C f$. GOMES, Paulo E. S. "A expressão social dos filmes 
de progresso e modernização do país em distintos contextos da República brasileira: a ditadura do Estado Novo (1937-1945); os "anos dourados", redivivos na memória coletiva brasileira pela presidência de Juscelino Kubitschek (1956-1960); e o Regime Militar (1964-1985) em seu ápice econômico e repressivo.

Convém lembrar que a trajetória dos cinejornais no Brasil foi bastante longeva ${ }^{2}$, o que se faz notar em algumas coleções ainda existentes em arquivos brasileiros, mas que tristemente representam uma pequena parte do que foi produzido. Neste quadro estão séries que se mantiveram mais coesas ao longo do tempo, sobretudo aquelas realizadas pelo governo federal e que, desta forma, carregaram o rótulo de propagandas oficiais, como o Cine Jornal Brasileiro (CJB) ${ }^{3}$; e cinejornais provenientes de companhias produtoras mais conhecidas, cuja importância econômica propiciou a exploração comercial aos seus realizadores ou detentores. Neste caso são exemplos os

documentais no cinema mudo brasileiro (1898 - 1930)", In: CALIL, Carlos Augusto (ed.) Paulo Emílio: Um Intelectual na Linha de Frente. São Paulo: Brasiliense; Rio de Janeiro: Embrafilme. 1986, pp. 323-328.

2 Presentes desde as primeiras décadas do século passado até meados dos anos 1980, os cinejornais compõem, em números absolutos, um terço da produção de filmes brasileiros, $c f$. Cinemateca Brasileira. "Filmografia Brasileira". Acessado em 01 de fevereiro de 2013. http://www.cinemateca.gov.br/. Para um breve panorama da produção de cinejornais no Brasil, $c f$. Archangelo, Rodrigo. "O papel dos cinejornais: os documentos da Atlântida Cinematográfica e do Canal 100". Revista da Cinemateca Brasileira. São Paulo: Cinemateca Brasileira. 2012, pp. 106-119.

3 Produzido entre 1938 e 1946 pelo Departamento de Imprensa e Propaganda (DIP), órgão oficial da propaganda varguista no Estado Novo. As edições aqui mencionadas pertencem ao acervo da Cinemateca Brasileira. 
jornais cinematográficos Notícias da Semana (NDS) e Atualidades Atlântida (ATA) ${ }^{4}$, e as séries conhecidas pela marca Canal $100^{5}$.

\section{Cine Jornal Brasileiro}

$\mathrm{Na}$ primeira experiência ditatorial da República brasileira, a obrigatoriedade de exibição dos complementos nacionais (curtas metragens ou cinejornais) nas sessões de cinema já vigorava, por decreto assinado pelo próprio Getúlio Vargas no início dos anos 1930 ${ }^{6}$. Assim, os planos do Estado Novo no cinema ${ }^{7}$ já contavam com um caminho pavimentado, no qual o CJB se consolidou como a primeira experiência oficial de propaganda cinematográfica estatal ${ }^{8}$. Com grande presença no circuito exibidor brasileiro, este cinejornal deu a ver uma ampla agenda de realizações em torno da figura do

\footnotetext{
${ }^{4}$ As séries Notícias da Semana (1945-1986) e Atualidades Atlântida (1942-1986) se destacaram por sua longevidade dentre os vários cinejornais produzidos pelo Grupo Severiano Ribeiro (GSR), importante cadeia de empreendimentos de cinema, com sede na cidade do Rio de Janeiro. O GSR marcou o campo cinematográfico nacional por sua reconhecida atuação nas atividades de produção, distribuição e exibição, e por estar à frente das "chanchadas", gênero de comédia musical brasileira produzida pela Atlântida Empresa Cinematográfica do Brasil S.A. (1941-1983), produtora que em 1947 fora incorporada ao GSR. As edições aqui mencionadas pertencem ao acervo da Cinemateca Brasileira.

5 Produzidas pela Produções Carlos Niemeyer Filmes Ltda., as séries Canal 100 Jornal, Canal 100 Revista e Canal 100 Atualidades surgiram em 1959 e foram unificadas em 1966 sob o nome de Canal 100 Jornal. Cf. Cinemateca Brasileira. Guia Cinemateca - Arquivos e Coleções. São Paulo: Cinemateca Brasileira, 2012, p. 38. As edições aqui mencionadas pertencem ao acervo da Cinemateca Brasileira.

${ }^{6}$ A primeira lei foi promulgada em 1932 (decreto 21.240/32), entrando em vigor apenas em 1934.

7 Como o Instituto Nacional do Cinema Educativo (INCE), oficializado em 1937 (seguindo ativo até 1966), cuja proposta foi produzir filmes como elemento de aprendizado e integração nacional, $c f$. SCHWARTZMAN, Simon (et.al.). Tempos de Capanema. São Paulo: Paz e Terra: FGV, 2000, pp. 104-107.

8 A respeito do CJB, a nossa referência é o trabalho pioneiro de SOUZA, José Inácio de Melo. O Estado contra os meios de comunicação (1889-1945). São Paulo: Annablumme: Fapesp, 2003.
} 
então ditador Vargas. Nas suas coberturas "cinejornalísticas", o DIP se inspirou nos cenários de regimes totalitários e empreendeu, por afinidade ideológica, um formato próximo ao das propagandas nazifascistas 9 , numa estética de culto ao $\operatorname{líder}^{10}$ que perdurou mesmo após o rompimento das relações diplomáticas com os países do Eixo, no início de 1942.

Em seus oito anos de existência, o CJB possuiu uma sequencia de abertura contendo várias atividades de um Brasil em marcha ${ }^{11}$, com imagens em movimento que compunham um caleidoscópio similar ao formato da bandeira nacional brasileira. Esta representação da uma nação una, semanalmente exibida em sua pujança, era a própria obra de Getúlio Vargas, e o uso do cinema para o recorrente elogio ao "chefe supremo" compôs com a estratégia - capitaneada pelo rádio e a imprensa escrita - de harmonizar os diferentes papéis dentro de uma ditadura. Em repetidas edições, a falta de democracia foi compensada com demonstrações de idolatria ao atencioso e onipresente líder carismático ${ }^{12}$ por parte do "trabalhador brasileiro", que era representado na chave de uma massa comportada em grandiloquentes comemorações cívicas ${ }^{13}$.

\footnotetext{
9 Para Lourival Fontes, idealizador e diretor do DIP até 1942, o objetivo de divulgar um projeto de nação em torno da liderança de Getúlio Vargas seria alcançado com a ajuda da propaganda particularmente inspirada no fascismo, do qual era abertamente simpático. Cf. ABREU, Alzira Alves de Abreu (et.al.) Dicionário Histórico-Biográfico Brasileiro pós-30. Rio de Janeiro: FGV: CPDOC, 2001, pp. 2260-2264.

${ }^{10}$ A esse respeito $c f$. CAPELATO, Maria Helena R. Multidões em Cena. Propaganda Política no Varguismo e no Peronismo. Campinas: Papirus, 1998.

11 "(...) com sucessivas aparições de navios de guerra em construção nos estaleiros, colheitas agrícolas abundantes, escolares em marcha, aviação", cf. SOUZA, José Inácio de Melo. "Trabalhando com cinejornais: relato de uma experiência", In: História: Questões e Debates n. 38, ano 20. Paraná: Associação Paranaense de História / UFPR, jan-jun 2003, pp. 43-62, p. 50.

12 Que "[...] visita, recebe, preside, assiste, discursa, excursiona, veraneia, embarca, retoma, parte, passeia, inicia, encerra, exorta, soluciona", cf. Tavares, Zulmira apud Souza, José Inácio de Melo. O Estado contra os meios de comunicação, op. cit., p.211.

13 A respeito do papel da massa na mitologia varguista, $c f$. SILVA, Zélia Lopes da. A Domesticação dos Trabalhadores nos Anos 30. Marco Zero, São Paulo, 1991;
} 
As festividades do Primeiro de Maio e do Sete de Setembro foram exemplos claros do ritualismo característico no governo estadonovista. Nesses eventos desfilaram o chefe da nação e as Forças Armadas (representadas também, por exemplo, pelas auxiliares Forças Públicas Estaduais, Polícia Militar e o Corpo de Bombeiros) como forças ativas na condução do Brasil. E em todos os quadrantes da nação brasileira mostrados no $\mathrm{CJB}$, estes dois polos exprimiam uma unidade nacional onde o povo - ou o trabalhador brasileiro - era o elemento passivo dessa equação. Enquanto Vargas faria de si um signo para os brasileiros, os militares encarnariam a segurança e a tranquilidade da manutenção territorial ${ }^{14}$. Nesse sentido, o objetivo foi fortalecer nacionalmente a personalidade de Vargas entrelaçando-a a temas como, por exemplo, economia, agricultura, indústria, progresso, etc., que sempre foram abordados de forma eloquente no CJB. Porém, vale lembrar que o tema "trabalho" teve uma frequência menor em relação aos demais, pois esta questão, noticiada de forma indireta, tomava o trabalhador como receptor do assistencialismo governamental, ou organizado em massa para adornar os festejos oficiais, incluindo também o aniversário do próprio presidente ${ }^{15}$.

Por outro lado, o tema "segurança nacional" foi o elo mais forte na aliança entre o ditador e os militares. Se a vigilância sobre a ameaça interna foi o mote para o combate ao comunismo, recorrentemente noticiado no $\mathrm{CJB}^{16}$; a ameaça externa ganhava impulso no contexto pós 1942 , com a propaganda cinematográfica de um

GOMES, Ângela Maria de Castro. A Invenção do Trabalhismo. Rio de Janeiro: Elume Dumará, 1994; e Capelato, Maria Helena R., op. cit.

14 SOUZA, José Inácio de Melo, idem, p. 211.

15 Que foi noticiado como parte do calendário oficial das comemorações cívicas. Idem, pp. 215-16.

16 Entre as edições sobre este tema, destacamos o CJB Vol.1 N.015 (1939), com a notícia "Luta contra o extremismo"; CJB Vol.1 N.075 (1939), “(...) Homenagem aos que tombaram na defesa das instituições brasileiras [no levante de 27 de Novembro de 1935, também conhecido por Intentona Comunista]"; CJB Vol.1 N.101 (1940), "(..) Escoltado pelos policiais paraenses, chega o carrasco do Partido Comunista."; CJB 
Brasil que não media esforços para cumprir seu papel de aliado, fosse com as participações da Força Expedicionária Brasileira e da Força Aérea Brasileira, ou nas imagens das ações de vigilâncias implementadas pelo Departamento de Ordem Política e Social (DOPS ${ }^{17}$. Nesse sentido, a propaganda feita em várias edições dos cinejornais do DIP18 estimulou a criação de um "inimigo nacional" e ajudou a disseminar o medo no imaginário coletivo, galvanizando, assim, uma nação imaginada enquanto atenta às ações inimigas ${ }^{19}$. Ao mesmo tempo imersa numa atmosfera de incerteza propícia às ações da ditadura em curso $^{20}$.

O Brasil representado semanalmente na propaganda oficial do CJB marcou a experiência "cinejornalística" brasileira não apenas por ter legado uma narrativa do culto ao líder, mas por propalar posicionamentos políticos e sociais conservadores nas telas de cinema.

Vol.1 N.178 (1940), "Heróis do Brasil - Rio: a inauguração do Mausoléu dos militares mortos na Defesa da Pátria, em novembro de 1935".

17 Criado em 1924, o DOPS (nome que sofreu mudanças, mantendo a sigla como denominação genérica), foi um órgão policial brasileiro que serviu à repressão e censura das ditaduras do Estado Novo (1937-1945) e do Regime Militar (1964-1985). Com instância federal e estadual, quase todas as unidades foram desativadas nos anos 1980. Seus respectivos arquivos, muitos sumariamente destruídos, ainda são foco de polêmica na revisão dos períodos de exceção democrática da história do Brasil.

18 Por exemplo, o CJB Vol.2 N.117 (1942), exposição com materiais de propaganda dos súditos do eixo; o CJB Vol.2 N.131 (1942), vítimas do bombardeamento de navios alemães; o CJB Vol.2 N.136 (1942), manifestação estudantil contra as forças do Eixo; o CJB Vol.1 N.169 (1942), missa em memória das vítimas de Pearl Harbor; o CJB Vol.3 N.092 (1944), edição especial com o "esforço de guerra" brasileiro; e o CJB Vol.4 N.023 (1945), festejo da vitória do Brasil no fim da guerra.

19 Afinidades como língua, religião, leis, ancestralidade e demais aspectos culturais são constitutivos da nação imaginada, aferida num determinado grupo a partir da comunhão desses valores ( $c f$. ANDERSON, Benedict. Comunidades Imaginadas: Reflexões Sobre a Origem e a Difusão do Nacionalismo. São Paulo: Companhia das Letras, 2008). Contudo, diante da ameaça à vida cotidiana, essa mesma nação pode subverter a comunhão de afinidades se apoderar do imaginário coletivo, assumindo a fatalidade da luta com principal elo do nacionalismo, $c f$. "A imaginação nacional", In: BALAKRISHNAN, Gopal (org.). Um Mapa da Questão Nacional. Rio de Janeiro: Contraponto, 2000, pp.209-225, p. 221.

20 Vale lembrar que o clima de incerteza e medo é um dos elementos "rentáveis" às construções mitológicas de regimes autoritários, cf. Giradet, Raoul. Mitos e Mitologias Políticas. São Paulo: Cia. das Letras, 1987, pp. 53-34. 
Nesta nação cinematográfica, o elogio à autoridade bebeu na estética fascista e estabeleceu refinados contornos à falta de protagonismo do povo que, massificado e sob um clima de vigilância, foi o maior ornamento simbólico à legitimidade da ditadura varguista.

\section{Notícias da Semana / Atualidades Atlântida}

$\mathrm{Na}$ fragmentada narrativa desses dois jornais cinematográficos, as notícias sobre diferentes esferas do todo social expõem as tensões contidas na representação dos grupos mostrados nas telas, sejam eles governos e governantes, cúpula política ou econômica, ou as diferentes classes sociais. Ações e intensões cinematograficamente construídas demonstram o quanto eles foram tributários de um imaginário social ${ }^{21}$, que também foi trabalhado para compor uma propaganda oficiosa do governo de Juscelino Kubitschek ${ }^{22}$.

Entre 1956 e 1960 o NDS e o ATA noticiaram uma agenda política com relevância ao desenvolvimento econômico. Exemplos desta postura foram as viagens internacionais do presidente Kubitschek pela Europa, Estados Unidos e América-Latina e a busca do país por sua independência econômica ${ }^{23}$; a realização de importantes obras de infraestrutura e a construção da nova capital Brasília ${ }^{24}$; a

21 Sobre a presença do imaginário social em imagens políticas, $c f$. BAECQUE, Antoine de. "Panfletos - Libelo e Mitologia Política" In DARNTON, Robert e Roche, Daniel (orgs.). Revolução Impressa - A Imprensa na França, 1775-1800. São Paulo: Edusp, 1996, pp. 225-238.

22 Observada pela grande quantidade de notícias de seu governo, bem como o tom elogioso sobre as realizações federais. Cabe mencionar que o GSR contou com as produções do fotógrafo e cineasta Jean Manzon (1915-1990), reconhecido por suas coberturas ufanistas sobre o Brasil, e elogiosas sobre a construção de Brasília. Sobre Manzon, $c f$. CARDENUTO, Reinaldo. "O Golpe no Cinema: Jean Manzon à sombra do Ipês”, In: MORETTIN, Eduardo et.al. (org.). História e Documentário. Rio de Janeiro: Editora FGV, 2012, pp. 119-149.

23 NDS. N.56X03, N.56X04, N.56X09, N.56X10 e N.56X32.

${ }^{24}$ NDS. N.57X42, N.58X27 e N.58X43; ATA. N.60X18. 
notoriedade internacional pela conquista do campeonato mundial do futebol em 195825; e uma nação com claros posicionamentos pró-bloco capitalista nas participações da ONU e em fóruns internacionais ${ }^{26}$. Ainda sobre o presidente, traziam o retrato de um líder com sua "doutrina Kubitschek" à frente da Operação Pan-americana em prol dos países latino-americanos ${ }^{27}$.

Os jornais cinematográficos do GSR destacaram as ações de instituições civis, militares e eclesiásticas, sobretudo pela atuação de seus líderes e representantes mais notórios - muitas vezes políticos, intelectuais e artistas, em eventos públicos ou privados. Assim como as produções estatais posteriores ao $\mathrm{CJB}^{28}$, os rituais do poder não ficaram de fora do que corriqueiramente o NDS e o ATA apresentaram solenidades com federações, organizações de classe e de segmentos da atividade econômica, clubes e associações, se articulando às organizações militares, hierarquias religiosas, partidos políticos e esferas de governo municipal, estadual e federal. Nestas situações, e nas notícias sobre as resoluções nos grandes centros - quase sempre com particular exaltação a deputados, vereadores, senadores, líderes de partidos e militares -, o tom da representação das classes sociais indica tensões entre a democracia e o status quo constituído. Nas demonstrações de poder levadas às salas de cinema, distintos papéis ostentaram uma hierarquia de valores ${ }^{29}$ enraizada no imaginário social. Diferentes camadas sociais da população foram representadas em seus comportamentos, aspirações e dramas na modernização da

\footnotetext{
25 NDS. N.58X28.

26 NDS. N.60X41 e N.60X43.

27 NDS. N.58X26 e N.58X32.

28 Como o Cine Jornal Informativo (1946-1969) produzido pela Agência Nacional.

29 Próprio da dimensão simbólica dos embates sociais. $C f$. BOURDIEU, Pierre. Coisas Ditas. São Paulo: Brasiliense, 2004, pp. 163 e 184.
} 
nação cinematográfica, retroalimentada também por uma cultura visual presente em outros meios como jornais e revistas ${ }^{30}$.

Nesses cincos anos, as notícias levaram ao público uma nação social e economicamente segregada em atos cotidianos. As ações da high society (sobretudo no Rio de Janeiro), por exemplo, foram mostradas não somente nos casamentos, bailes de debutantes e voos da aviação comercial brasileira que "ligavam" o Brasil, mas também na solidariedade com os pobres, expressa em chás beneficentes, bailes filantrópicos e desfiles de modas em locais luxuosos ${ }^{31}$. Nesse sentido, as primeiras-damas e as "distintas senhoras" representavam o status e as ações políticas de seus respectivos esposos e familiares, protagonistas nos círculos decisórios da época ${ }^{32}$. Para além do colunismo social de jornais e revistas, as imagens reiteravam as cercanias sociais internas de uma nação.

Neste mesmo cenário, assistia-se ao desenvolvimento econômico brasileiro por meio de notícias sobre a expansão do parque industrial ${ }^{33}$, a implantação de extenso plano viário ${ }^{34}$, as remodelações urbanas nos grandes centros ${ }^{35}$, os planos habitacionais ${ }^{36}$ e os novos

30 A cultura visual na chave de um "olhar de época", como o pintor quatrocentista que se apoiava nos códigos visuais compartilhados pelo seu público/clientela. Cf. BAXANDALL, Michael. O Olhar Renascente: Pintura e Experiência Social na Itália da Renascença. Rio de Janeiro: Paz e Terra, 1991, p.48. Nesse sentido, os cinejornais apresentaram imagens colhidas da experiência e hábitos visuais do público, no que contribuíram para engendrar uma cultura audiovisual do período.

31 NDS. N.56X21, N.56X25, N.57X21, N.57X24, N.57X26, N.57X44, N.57X31, N.57X39, N.57X49, N.57X53, N.58X02, N.58X22, N.58X23, N.58X36, N.58X38, N.58X44, N.59X20, N.59X28, N.59X30, N.59X49, N.60X07, N.60X12, N.60X34 e N.60X41.

32 Cf. SÁNCHEZ-BIOSCA, Vicente. Cine de Historia Cine de Memória - la representación y sus limites. Madrid: Cátedra. 2006, p. 49.

33 NDS. N.56X20, N.57X07, N.59X28, N.58X04, N.58X06, N.59X10, N.59X39, N.59X43, N.59X47, N.59X48 e N.60X24.

34 NDS. N.56X41, N.57X16, N.58X06, N.59X02, N.59X05, N.59X39 e N.60X39.

35 NDS. N.56X12, N.57X45, N.58X02, N.58X30, N.58X40, N.59X02, N.59X42, N.60X22, N.60X38, N.60X39, N.60X47 e N.60X51.

36 NDS. N.56X46, N.56X47, N.57X23, N.57X43, N.57X48, N.57X52, N.57X53, N.58X04, N.59X42, N.59X48, N.60X12 e N.60X50. 
padrões capitalistas de consumo, potencializados com a introdução de novidades no mercado e no vocabulário brasileiro ${ }^{37}$. Ou seja, imagens de um país imerso numa atmosfera de incremento e estímulo ao american way life, algo reforçado pelas elogiosas notícias sobre o comportamento da sociedade norte-americana, trazidas pelo "nosso correspondente" internacional ${ }^{38}$. Nesse sentido, o NDS e o ATA também repercutiam o poder político e econômico norte-americano, algo condizente às importantes atividades do GSR - como distribuição e exibição - que cresceram no domínio hollywoodiano sobre o mercado cinematográfico brasileiro. Convenientemente, tais interesses contribuíram para a aproximação do GSR com o campo político no acirrado contexto da guerra-fria, na medida em que exibia para o público de suas salas um país pró Estados Unidos, com críticas aos seus opositores e manifestações cotidianas contra o comunismo ${ }^{39}$.

Inseridas no circuito de exibição em massa, tais representações no cinema contribuíram para divulgar posicionamentos conservadores em defesa da família e da propriedade, e situar os setores médios numa rotina distante da parcela pobre da população. Desta forma, o avanço da modernidade precisava ser protegido de qualquer retrocesso, que poderia vir ideologicamente travestido na ameaça socialista/ comunista e, por isso, legitimava o apelo à manutenção da ordem

37 NDS. N.56X41, exposição da indústria mecânica; N.56X25, N.57X49, N.58X44 e N.59X40: fábrica de brinquedos; N.59X30, inauguração de concessionárias automobilísticas; N.60X14, exposição de utilidades domésticas; N.60X37, carro de luxo produzido no Brasil; N.60X49, Salão Brasileiro do Automóvel; N.60X33, exposição de produtos têxteis nacionais; N.58X07, inauguração de reator atômico brasileiro; N.60X39 e N.60X43: o primeiro "cérebro eletrônico" no Brasil.

38 Em NDS. N.60X23, o próprio cinejornal noticiou a decisão do Serviço de Diversões Públicas, em permitir a veiculação de material estrangeiro nos cinejornais. Para o GSR tratava-se de um "novo passo" para a indústria cinematográfica brasileira.

39 NDS. N.56X04, N.56X33, N.56X48, N.56X49, N.56X50, N.56X51, N.57X09, N.58X05, N.58X26, N.58X32, N.58X42, N.58X46, N.59X21, N.59X24, N.60X33, N.60X35, N.60X36, N.60X37, N.60X41, N.60X42 e N.60X43. E continuaram pelo ano seguinte: NDS. N.61X04, N.61X12, N.61X21, N.61X22, N.61X34, N.61X36, N.61X38, N.61X44, N.61X47 e N.61X50. 
e do progresso. Uma vez mais, o inimigo mostrado em cinejornais estava à espreita para minar a felicidade de toda uma nação, mas, ao contrário do que fora mostrado anos antes no CJB, tratava-se de proteger o avanço proporcionado por um democrático - mas excludente - desenvolvimento capitalista. Nem que para isso fosse necessária uma postura autoritária frequentemente demonstrada nos aperfeiçoamentos de órgãos especializados como o DOPS, ou em demonstrações públicas da Polícia Militar sobre como debandar manifestações públicas ${ }^{40}$.

No contexto democrático mostrado pelo NDS e o ATA, o "povo" foi um simples espectador nos episódios que envolveram crises políticas ${ }^{41}$. Nestes registros, representantes da elite econômica eram os protagonistas na mise-en-scène palaciana dos eventos decisivos da vida nacional. Num mesmo movimento, a presença dos setores médios foi mostrada pela atuação de suas entidades e representantes classistas ${ }^{42}$; enquanto o povo, na chave da "classe trabalhadora", foi raramente retratado nas ações de seus sindicatos, sendo estes criticados por atos de greve nas poucas aparições nos cinejornais do GSR ${ }^{43}$. Nessa narrativa semanal até mesmo a Igreja contribuiu, no exercício de seu ofício cristão, para sedimentar a estratificação social. Na medida em que era notícia o povo desfavorecido recebedor de ações contra a carestia ${ }^{44}$, corroborando imageticamente o olhar

40 NDS. N.58X05, exposição de material comunista apreendido; N.58X16 e N.58X18: autoridades brasileiras em treinamento junto ao FBI; N.58X42, conferência do diretor do DOPS sobre a apreensão de material "vermelho"; N.58X19 (e também em 1961: N.61X52), solenidades em que a Polícia Militar demonstra táticas para dispersar "aglomerações populares e comícios"; e logo após o governo Kubitschek, no NDS. N.61X21, o treinamento das Polícias Militares junto ao Exército Norte-Americano.

41 NDS. N.55X49; ATA. N.56X02.

42 ATA. N.56X01, N.56X20, N.56X26 e N.57X32; NDS. N.56X19, N.56X23, N.56X51, N.57X38, N.57X53, N.58X27, N.58X36, N.58X42, N.59X19, N.58X43, N.59X12, N.59X29, N.59X38 e N.59X47.

43 NDS. N.57X29, N.58X24, N.58X48, N.59X23 e N.59X51.

44 NDS. N.56X14, N.56X28, N.56X39 e N.57X04. 
filantrópico da alta sociedade. Decerto, essas representações colaboraram para galvanizar a imagem da parcela pobre como elemento passivo e perdido diante da modernização, além de sequioso por iniciativas de assistencialismo que compensariam a insuficiência do Estado em suas obrigações. Algo evidente no tom condolente das notícias sobre a carestia, o sofrimento em regiões menos desenvolvidas ${ }^{45}$, ou tragédias como a seca no Nordeste, enchentes ou incêndio em favelas ${ }^{46}$. Algo que compôs o elogio elitista à pobreza da nação, mostrada como nascedouro de gente talhada para enfrentar infortúnios e obstáculos, como no exemplo do deslocamento candango para a construção de Brasília ${ }^{47}$.

Para que seu governo fosse reconhecido por conquistas econômicas e o respeito à democracia - claudicante em seu histórico de retrocesso e tragédia ${ }^{48}$-, Kubitschek necessitou publicizar sua agen$\mathrm{da}$, no que contou com os cinejornais da maior cadeia de atividades cinematográficas à época: o GSR. As imagens e sons oficiosos do NDS e do ATA mostraram Kubitschek liderando uma nação conciliatória e solidária entre suas classes sociais. Porém, eles carregaram os silêncios que compuseram uma memória monumentalizada do período, bem como a mitologia política do conhecido presidente. Nesses silêncios, é exemplar a quase ausência de notícias sobre

45 NDS. N.56X48, a falta de abastecimento em favela do Rio de Janeiro; N.57X18, a carência de estradas para o Nordeste; N.57X06, N.57X07, N.57X08, N.58X21, N.59X03 e N.59X08: a seca no Nordeste; N.58X18, com a ajuda norte-americana para o povo nordestino.

46 NDS. N.56X34, N.57X04, N.57X36, N.59X02, N.59X04, N.59X43, N.60X16, N.60X17 e N.60X19.

47 Dentre poucas notícias sobre os candangos, o NDS. N.60X1 menciona, na inauguração de Brasília, um desfile de "operários anônimos que vieram de todo o Brasil para construir Brasília". Em NDS. N.60X37, o foco foi a "inciativa" da administração da nova capital em sortear um automóvel em reconhecimento a todos os candangos.

48 Por exemplo, a ditadura do Estado Novo; o suicídio do presidente Getúlio Vargas a 24 de agosto de 1954; e a tentativa de impugnação da eleição de Kubitschek e seu vice Joao Goulart, em eventos ocorridos em novembro de 1955. 
sindicatos e associações trabalhistas, fossem urbanas ou rurais ${ }^{49}$, num governo cuja força política também repousou na aliança com o Partido Trabalhista Brasileiro (PTB), sigla do vice-presidente João Goulart. Assim como sintomático foi o ofuscamento das camadas populares na construção cinematográfica da nação, cuja pobreza, nada aprazível à representação estética de um país moderno, foi retratada como efeito colateral do processo de modernização. Processo este em que a elite econômica e os setores mais conservadores desfilaram como peças-chave da governabilidade. Nas notícias sobre as iniciativas federais, o elogio recaiu sobre os empresários: promotores do bem-estar do povo, tanto na melhoria de regiões atrasadas, como na construção de indústrias para o progresso brasileiro ${ }^{50}$. Nesse sentido, os rituais do poder nesses cinejornais continuaram exibindo o povo como mero observador nas tomadas de decisões.

\section{Canal 100}

Fundada em 1959, a Produções Carlos Niemeyer Filmes Ltda. teve por objetivo a produção de cinejornais, e o título Canal 100 aludia à televisão brasileira, à época com pouquíssimos canais e muito longe de sintonizar três dígitos nos televisores domésticos - ainda incipientes no Brasil. Com produção contínua até 1986, esse cinejornal legou um grande mosaico com imagens em movimento que, hoje, são testemunhos de transformações socioculturais e políticas, além de propagandas oficiosas da ditadura civil-militar brasileira, notadamente em seu ápice antidemocrático e do êxito econômico51.

49 Exceção feita às comemorações do Primeiro de Maio, nos moldes das conhecidas cerimônias mostradas pelo CJB: NDS. N.56X20, N.57X20, N.58X19 e N.59X19.

50 NDS. N.57X07, N.59X08, N.59X18, N.60X40 e N.60X42.

51 Período situado entre 1968, ano marcado pelo acirramento contra as liberdades individuais com a decretação do Ato Institucional N. ${ }^{\circ}$, e o fim do mandato do 
Exibidos semanalmente no eixo Rio-São Paulo, e com certo atraso em outras regiões brasileiras, as edições do Canal 100 apresentavam uma revista semanal que quase sempre encerrava com partidas de futebol, sua principal característica. Vale dizer que o futebol mostrado no Canal 100 talvez seja o dado mais imediato na memória coletiva sobre um cinejornal brasileiro, lembrado principalmente pelo acompanhamento da música $\mathrm{Na}$ cadência do samba de Luís Bandeira, e seu célebre seu refrão "que bonito é..." Contudo, suas edições também se notabilizaram pela amplitude dos temas noticiados nos anos 1960 e 1980: padrões comportamentais da juventude ${ }^{52}$; sucessos da indústria musical e do entretenimento ${ }^{53}$; melhoramentos nas capitais brasileiras ${ }^{54}$; beldades como a garota de Ipanema Helô Pinheiro e a estrela Brigitte Bardot ${ }^{55}$; visitas diplomáticas do xá iraniano Reza Pahlavi56 e da rainha Elizabeth II ${ }^{57}$, dentre várias; a fé católica arregimentada contra a "ameaça comunista" 58; e outros esportes como as corridas de F-1 de Emerson Fittipaldi59 e os eventos de jiu-jitsu da reconhecida família Grace ${ }^{60}$.

presidente Emílio Garrastazú Médici, que governou de 30 de outubro de 1969 a 15 de março de 1974.

52 Canal 100. N.67X39.

53 Canal 100. N.69X41 e N.70X35.

54 Canal 100. N.68X5 e N.70X01.

55 Canal 100 Atualidades. N. 65X01 e Canal 100 Revista. N.64X03.

56 Canal 100 Jornal. N. 65X20.

57 Canal 100 Jornal. N. 68X47.

58 Ocorrida em várias capitais brasileiras, a "Marcha da Família com Deus pela Liberdade" foi a demonstração pública mais acabada do conservadorismo católico, que apoiou a deposição de João Goulart em favor do golpe civil-militar. Em abril de 1964 foi às ruas do Rio de Janeiro, para celebrar o golpe civil-militar: na fala do narrador "a fé sempre existiu, com Deus e pela liberdade o povo foi às ruas para saudar a nova era que se afirmava no país". Canal 100 Jornal. N.65X01.

59 Canal 100. N.73X09.

60 Canal 100 Jornal. N. 74X23 e N.75X29. 
Mesmo com a expansão da telecomunicação a partir de $1965^{61}$, os presidentes militares também se valeram da evidência proporcionada pelo Canal 100 nas salas de cinema do país. Aliás, o tom elogioso na divulgação da agenda do governo federal (que "colaborava" com patrocínio do banco Caixa Econômica Federal) esteve presente logo no início da ditadura: na cobertura do golpe civil-militar em 31 de março de 1964, rememorado em retrospectiva exibida em janeiro de $1965^{62}$. Assim como o CJB e os cinejornais do GSR, o Canal 100 também apresentou um ritualismo característico. Mas neste caso, o culto ao poder repousou na exaltação ao "berço esplêndido" de um país bem governado pelos militares. Na sequência de abertura mais conhecida deste cinejornal, a nação foi representada numa montagem que harmonizava atividades esportivas, militares, desfiles cívicos e a beleza brasileira, representada nas praias e nas mulheres do Rio de Janeiro, "cidade maravilhosa" não raro elogiada em eventos estritamente políticos ${ }^{63}$. Porém, o ufanismo mais exposto nesse cinejornal lançou mão de uma recorrente identidade brasileira: o futebol.

As coberturas deste esporte colocaram de forma inédita, sobretudo em jogos da Copa do Mundo, o governo federal no epicentro desta importante manifestação do imaginário coletivo. As imagens e sons registrados pelo Canal 100 legaram um padrão inovador à representação do futebol, elevando-o à categoria de poderoso autoelogio à brasilidade, abertamente utilizado em respaldo do Regime Militar.

61 Para o sociólogo Renato Ortiz, entre 1964 e 1980 ocorreu, no Brasil, uma forte expansão de bens culturais, em que a televisão brasileira atingiu, em 1975, o posto de nono mercado do mundo. Cf. ORTIZ, Renato. Cultura Brasileira e Identidade Nacional. São Paulo: Brasiliense, 2006, pp.83-84.

${ }^{62}$ Canal 100 Jornal. N.65X01. É esclarecedora a fala do narrador, que exalta o ato militar que tirou o país "da beira de um abismo" e baniu a "corrupção e a subversão", que "levou às ruas tanques e armas, mas não derramou sangue de ninguém", e reuniu "todas as camadas em torno da mesma ideia". $C f$. ARCHANGELO, Rodrigo, "O papel dos cinejornais: os documentos da Atlântida Cinematográfica e do Canal 100”, op. cit.

63 Canal 100 Jornal. N.67X37. 
Numa narrativa audiovisual monumental, dramatizou-se o espetáculo em todas as instâncias: os acertos e os erros dos jogadores em ângulos e tomadas inéditas; a ida do torcedor até o estádio, ligando o evento da partida ao cotidiano dos cidadãos; rostos, gestos e comportamentos de uma torcida em primeiro plano, denotando sensações de entusiasmo e identificação emocional com os ídolos, equipas e a Seleção Brasileira. Foi neste chave que o culto ao poder no Canal 100 concedeu protagonismo à massa, embora a despindo de conotações político-ideológicas. A própria torcida mostrada nas arquibancadas e noutros lugares do estádio foi a mais acabada representação da sociedade brasileira e do sentimento nacional: subordinados e superiores, pobres e ricos, pretos e brancos, mulheres e homens participando do mesmo evento.

O Canal 100 oferecia imagens de uma "união brasileira", que se sobrepunha às enormes diferenças sociais e econômicas, alimentando um nacionalismo necessário à estratégia de uma ditadura em curso. Nas atuações da Seleção Brasileira, por exemplo, as cinematográficas vitórias reforçaram a experiência de igualdade e justiça social, num cenário de regras simples e de plena liberdade de opinião, onde a autoridade personificada no juiz era contestada e até xingada pelo cidadão brasileiro pobre e legítimo representante da massa. Com o reforço do futebol por esse cinejornal, fortalecia-se a pseudodemocracia do Regime Militar em inúmeras salas de cinema, uma vez que era mostrada a alternância entre vitoriosos e perdedores, de opostos com chances iguais, numa situação fictícia em quase toda a existência do Canal 100.

Dos estádios aos circuitos exibidores em várias cidades brasileiras, o espetáculo das massas proporcionado pelo futebol foi a maior contribuição do Canal 100 ao governo brasileiro, pois franqueou o seu discurso de crescimento e progresso. Logo, o Brasil acontecia dentro e fora do campo, conectando uma prática popular ao poder do Estado, apanágio de uma elite que o tomara num golpe civil-militar. Em inúmeras edições desse cinejornal, o futebol foi o assunto semanal que encerrou edições plenas de representações da vida social, 
política e econômica. Nas arquibancadas, a tensão e a expectativa nos rostos populares era o necessário retrato do povo torcendo por um Brasil cinematográfico. Nesta ótica, avançar no gramado significava avançar nos rumos do país, um discurso que se viu reforçado na Copa de 1970, em pleno ápice do "milagre econômico brasileiro". Na partida final deste evento, o Canal 100 estabeleceu, pelos dispositivos cinematográficos, a continuidade entre o Regime Militar e o que o Brasil tinha de melhor a mostrar aos próprios brasileiros ${ }^{64}$. Naquele contexto, nenhum cinejornal representou tão bem o poder se apropriando de uma manifestação legítima da cultural brasileira.

\section{Contornos da nação: a cultura do poder nos cinejornais}

Todos os cinejornais mencionados trazem à tona uma agenda política, o que não é novidade nesse tipo de cinema ${ }^{65}$. Porém, eles também estendem a política para outros campos da atividade coletiva $^{66}$, se valendo de signos, valores e níveis de comportamento que subsidiaram uma cultura do poder noticiada com imagens em movimento. Assim, curta e longa duração de um autoritarismo estão imbricados aos contornos da nação brasileira delineados pelo ritualismo e movimentações sociais registrados no noticiário cinematográfico.

64 Como na sequência em que o presidente Médici, ao recepcionar os campeões da Copa de 1970 na capital da República, ergue a Taça Jules Rimet num gesto ensaiado para as câmeras, valendo-se de um gesto consagrado por capitães da Seleção Brasileira em três conquistas mundiais. Para o Regime Militar, era preciso mostrar ao povo o sucesso de um país bem governado. Canal 100. N.70X28.

65 Que também repercutiu um ritualismo político na chave de uma "investidura" partidária, como aponta SOUZA, José Inácio de Melo, "Eleições e Cinema Brasileiro: do fósforo eleitoral aos santinhos eletrônicos", In: Revista da USP $n^{\circ} 22$. São Paulo: USP, jun-ago, 1994, pp. 155-65.

66 RÉMOND, René. 2003. "Do Político", In: RÉMOND, René, ed. 2003. Por uma História Política. Rio de Janeiro: FVG, pp. 441-450, 447. 
No rápido retrato de duas ditaduras e um interregno democrático, os apontamentos demonstram o potencial dessas séries para compreender comportamentos e atitudes do universo político e sociocultural brasileiro. Em três momentos abordados veem-se discursos que encorparam, com nuances, contornos de uma nação em pleno lema "ordem e progresso": no CJB, um Brasil personificado no ditador e nas forças de segurança em tempos de guerra, ambos reverenciados em imagens com os primeiros ensaios da massa ordenada; no NDS e no ATA a clara omissão, e por vezes segregação, da massa pobre na composição estética da nação em pleno desenvolvimento capitalista; e, no Canal 100, o país exaltado pela massa cujo protagonismo só foi mostrado nos limites apolíticos das arquibancadas do espetáculo de futebol. Enfim, trata-se da encenação semanal do ritual do poder protagonizado pela elite política e econômica brasileira, numa práxis que monumentalizou sua dimensão decisória, o elogio ao que the conveio e sua demonstração de força perante o todo social.

Dentre tantos aspectos a serem observados e compreendidos na nação desenhada nesses cinejornais, talvez um dos mais necessários seja uma possível estética da ordem. Por ora, uma ideia algo abrangente, mas que denota como essa forma de cinema aprimorou, em sua tradição, a incorporação da vida cotidiana ao representar uma nação conservadora, contraparte da modernidade e do desenvolvimento exibidos nas telas. Neste caminho, esses jornais cinematográficos mostraram uma passiva população brasileira, simples observadora de atos políticos e econômicos, alijada na topografia visual e sonora das decisões políticas, e massificada nas comemorações e desfiles de efemérides. Lançaram mão da pobreza como argumento a ser lembrado, pela voz do narrador, em eventos beneficentes; ou como objeto para as câmeras nas tragédias, infortúnios e ações assistencialistas. Optaram por traduzir a modernidade em instalações fabris, melhoramentos em aeroportos e rodovias, em desfiles de moda, exposições e feiras das novidades de consumo; e a personificaram em gestos e 
sorrisos ansiosos por bens duráveis e culturais fora do alcance de grande parte da população, inclusive da própria classe média. Nas ditaduras, alimentaram elogiosas representações cinematográficas das forças armadas, alardeando ações e treinamentos também em tempos democráticos para deter o inimigo interno e externo - que quase sempre existiu apenas no texto de locução das notícias. E em longos planos-sequencia, encenaram os rumos do país capitaneado pela elite política e econômica, enquanto o povo, nas panorâmicas das arquibancadas e nos close-ups de rostos aflitos e exultantes, torcia pelos lances do Brasil em campo.

Em suma, uma estética que não pôde ser detalhada nos limites desta apresentação, mas que é intrínseca à cultura do poder nesses cinejornais - irrestrita às duas ditaduras, pois também deu forma às representações com pouca participação democrática nos anos do governo Kubitschek. Ou seja, uma estética que moldava imagem e som para referendar as atitudes dos palácios e quartéis, donde emanava, de fato, o poder em cena. Para melhor compreendê-la serão necessários seguidos visionamentos das imagens cinematográficas, atentas leituras de documentos correlatos e uma indagação interessada em traduzir a alteridade e recompor a trama dos significados, despindo-os da memória posteriormente estabelecida ${ }^{67}$. Coincidência histórica ou não, os jornais cinematográficos brasileiros acabaram quando o país renascia democraticamente ${ }^{68}$. Neste contexto de recuo da postura antidemocrática no cenário político brasileiro, o elogio ao poder não mais se mostraria em cinejornais, mas as imagens em movimento dessa cultura do poder seguiriam traçando os contornos da sua nação brasileira, especialmente por ondas eletromagnéticas.

67 FARGE, Arlette. O Sabor do Arquivo. São Paulo: Edusp, 2009, pp. 35-37, 93.

68 O Conselho Nacional e Cinema (CONCINE), em Resolução ${ }^{\circ} 117$ de 25 de janeiro de 1985, proibiu o teor publicitário nos jornais cinematográficos, e fixou o limite de três minutos de duração. Tais medidas, na prática, minaram toda e qualquer iniciativa dos realizadores de cinejornais. 